\title{
Peptidergic Nociceptors of Both Trigeminal and Dorsal Root Ganglia Express Serotonin 1D Receptors: Implications for the Selective Antimigraine Action of Triptans
}

\author{
Sonja Potrebic, ${ }^{1,4 \star}$ Andrew H. Ahn, ${ }^{1,2,4 *}$ Kate Skinner, ${ }^{2,4}$ Howard L. Fields, ${ }^{1,3,4}$ and Allan I. Basbaum ${ }^{2,3,4}$ \\ Departments of ${ }^{1}$ Neurology, ${ }^{2}$ Anatomy, and ${ }^{3}$ Physiology and ${ }^{4}$ W. M. Keck Foundation Center for Integrative Neurosciences, University of California, San \\ Francisco, San Francisco, California 94143
}

\begin{abstract}
Agonists at serotonin 1D $\left(5-\mathrm{HT}_{1 \mathrm{D}}\right)$ receptors relieve migraine headache but are not clinically used as general analgesics. One possible explanation for this difference is that $5-\mathrm{HT}_{1 \mathrm{D}}$ receptors are preferentially expressed by cranial afferents of the trigeminal system. We compared the distribution of $5-\mathrm{HT}_{1 \mathrm{D}}$ receptor-immunoreactive $\left(5-\mathrm{HT}_{1 \mathrm{D}}-\mathrm{IR}\right)$ peripheral afferents within the trigeminal ganglion (TRG)

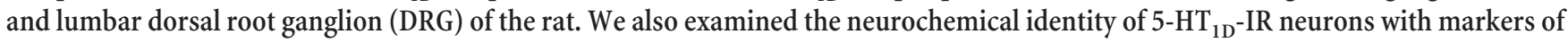
primary afferent nociceptors, peripherin, isolectin B4, and substance P, and markers of myelinated afferents, N52 and SSEA3. We observed a striking similarity in the size, distribution, and neurochemical identity of 5- $\mathrm{HT}_{1 \mathrm{D}}$-IR neurons in TRG and lumbar DRG afferents. Furthermore, the vast majority of 5-HT $1 \mathrm{D}-\mathrm{IR}$ neurons are unmyelinated peptidergic afferents that distribute peripherally, including the dura, cornea, and the sciatic nerve. In the central projections of these afferents within the trigeminal nucleus caudalis and the spinal cord dorsal horn, $5-\mathrm{HT}_{1 \mathrm{D}}$-IR fibers are concentrated in laminas I and outer II; a few axons penetrate to lamina V. At the ultrastructural level, $5-\mathrm{HT}_{1 \mathrm{D}}$ receptors in the spinal cord dorsal horn are localized exclusively within dense core vesicles of synaptic terminals. We observed scattered $5-\mathrm{HT}_{1 \mathrm{D}}-\mathrm{IR}$ neurons in the nodose ganglia, and there was sparse terminal immunoreactivity in the solitary nucleus. The visceral efferents of the superior cervical ganglia did not contain 5- $\mathrm{HT}_{1 \mathrm{D}}$ immunoreactivity. Our finding, that 5-HT $_{1 \mathrm{D}}$ receptors are distributed in nociceptors throughout the body, raises the possibility that triptans can regulate not only headacheassociated pain but also nociceptive responses in extracranial tissues.
\end{abstract}

Key words: serotonin receptor; substance P; migraine pain; trigeminal; dorsal root ganglion; ultrastructure

\section{Introduction}

Migraine is a common and disabling disorder with periodic headache and sensory symptoms that affects up to $13 \%$ of men and $33 \%$ of women during their lifetime (Launer et al., 1999). The introduction of agonists that activate serotonin $1 \mathrm{~B}\left(5-\mathrm{HT}_{1 \mathrm{~B}}\right)$ and $5-\mathrm{HT}_{1 \mathrm{D}}$ receptors (the "triptans") has revolutionized treatment for many migraineurs. Despite the remarkable efficacy of triptans, neither the anatomical site of action nor the receptor subtype responsible for their clinical efficacy is known (Goadsby et al., 2002).

Systemic administration of triptans reduces responses in trigeminal nucleus caudalis neurons evoked by dural or facial stimulation (Cumberbatch et al., 1997, 1999; Storer and Goadsby, 1997; Hoskin and Goadsby, 1998). Triptans may directly modulate afferent activity, because in situ hybridization studies have

Received June 30, 2003; revised Sept. 26, 2003; accepted Sept. 29, 2003.

This work was supported by National Institutes of Health Grants NS02237 (S.P.), NS21445, and NS14627, a GlaxoSmithKline/American Headache Society Research Award from the American Headache Society (A.H.A.), and a Postdoctoral Fellowship from the Howard Hughes Medical Institute (A.H.A.). We thank Katarina Sanderson-Nydhal for preparation of sciatic nerve ligation samples.

* S.P. and A.H.A. contributed equally to this work.

Correspondence should be addressed to Andrew H. Ahn, University of California, San Francisco, Box 0452, Room HSE 819, 513 Parnassus Avenue, San Francisco, CA 94143-0452. E-mail: aahn@itsa.ucsf.edu. Copyright $\odot 2003$ Society for Neuroscience $\quad 0270-6474 / 03 / 2310988-10 \$ 15.00 / 0$ identified 5- $\mathrm{HT}_{1 \mathrm{~B}}$ and 5- $\mathrm{HT}_{1 \mathrm{D}}$ receptor mRNA in the trigeminal ganglion (TRG) (Bruinvels et al., 1994; Bonaventure et al., 1998). Consistent with this view, a colocalization study on human trigeminal ganglia suggests that activation of $5-\mathrm{HT}_{1 \mathrm{D}}$ receptors may inhibit nearly all peptidergic nociceptors (Hou et al., 2001). The latter study differs from other studies, however, in which only one-half of the peptidergic nociceptors also express the 5- $\mathrm{HT}_{1 \mathrm{D}}$ receptor (Bonaventure et al., 1998; Ma et al., 2001). This numerical discrepancy may have distinct functional implications for how triptans modulate afferent activity and emphasizes the importance of knowing the neurochemical properties of the primary afferents bearing the triptan receptors.

In this regard, it is of particular interest that $5-\mathrm{HT}_{1 \mathrm{~B}}$ receptor mRNA has been demonstrated in both TRG and lumbar dorsal root ganglion (DRG) afferent neurons (Wotherspoon and Priestley, 2000), and reverse transcription-PCR studies have detected $5-\mathrm{HT}_{1 \mathrm{~B}}$ and $5-\mathrm{HT}_{1 \mathrm{D}}$ receptor mRNA in both TRG and DRG (Pierce et al., 1997; Bouchelet et al., 2000). The presence of these receptors in extracranial afferents raises the possibility that triptans may be generally analgesic. In fact, a few studies suggest that triptans are analgesic in animal models of noncranial pain (Kayser et al., 2002) and can reduce evoked activity in the spinal cord of the rat (Cumberbatch et al., 1998). The preponderance of evidence, however, points to the specific clinical utility of triptans 
in treating certain types of cranial pain, such as migraine, cluster headache (Ekbom et al., 1995), and corneal eye pain (May et al., 2002), and the inability of triptans to demonstrate analgesia in other kinds of facial pain (al Balawi et al., 1996; Antonaci et al., 1998), somatic pain (Dao et al., 1995), and animal models of acute pain (Skingle et al., 1990).

The disagreement among laboratories concerning the distribution of $5-\mathrm{HT}_{1 \mathrm{~B} / \mathrm{D}}$ receptors makes it difficult to understand the remarkable specificity of triptans. To address this question, we raised and characterized a sensitive and specific antibody to the $5-\mathrm{HT}_{1 \mathrm{D}}$ receptor. We report that afferents with $5-\mathrm{HT}_{1 \mathrm{D}}$ receptor are peptidergic nociceptors whose number and neurochemistry are indistinguishable in TRG and DRG.

\section{Materials and Methods}

\section{Production of 5-HT $T_{1 D}$ receptor subtype-specific antiserum}

We chose a subtype-specific region of the $5-\mathrm{HT}_{1 \mathrm{D}}$ receptor by alignment of the published protein sequences of $5-\mathrm{HT}_{1 \mathrm{~B}}, 5-\mathrm{HT}_{1 \mathrm{D}}$, and $5-\mathrm{HT}_{1 \mathrm{~F}}$ receptors in mouse, rat, guinea pig, and human. The peptide selected corresponds to amino acids $226-240$ ( $\operatorname{Lys}^{226}-\mathrm{Gln}^{240}$ ) translated from the cDNA sequence in rat. An N-terminal cysteine was added to the synthetic oligopeptide, CLNPPSLYGKRFTTAQ.

We obtained antiserum from rabbits by standard methods. Briefly, the oligopeptides were conjugated to maleimide-activated keyhole limpet hemocyanin (KLH) and bovine serum albumin (BSA) haptens and used to immunize two rabbits. The animals were first immunized with KLHlinked peptide and complete Freund's adjuvant and subsequently boosted with BSA-linked peptide and incomplete Freund's adjuvant. Enzyme-linked immunosorbent assay was used to assess resulting antiserum. The rabbits were exanguinated, the sera were combined for affinity purification over a column linked to the oligopeptide and eluted, and IgG fractions were combined. Polyclonal antiserum was produced by Animal Pharm Services (Healdsburg, CA).

\section{Light microscopy}

Tissue preparation. Sprague Dawley rats (175-250 gm) were overdosed with sodium pentobarbital and perfused with saline, followed by fixation with $10 \%$ Formalin in $0.1 \mathrm{~m}$ sodium phosphate buffer, $\mathrm{pH}$ 7.4. The L5 DRG, TRG, nodose ganglia, superior cervical ganglia, and sciatic nerve were collected, postfixed for $2 \mathrm{hr}$, and cryoprotected overnight in $30 \%$ sucrose in $0.1 \mathrm{~m}$ sodium phosphate buffer, $\mathrm{pH}$ 7.4.

A pair of L5 DRG and TRG from the same animal was grouped en bloc, and serial $14 \mu \mathrm{m}$ cryostat sections were cut and mounted on slides. Sciatic nerve, nodose ganglia, and superior cervical ganglia were also cut as $14 \mu \mathrm{m}$ cryostat sections and mounted on slides in series. Three animals were used in each series.

Dural tissue was collected after perfusion and processed as a whole mount. To collect corneas, the eyes were superfused with fixative during the intracardiac saline perfusion. The orbits were enucleated and postfixed for $2 \mathrm{hr}$ before cryoprotection overnight in 30\% sucrose. The cornea and surrounding limbus were dissected free and cut as $30 \mu \mathrm{m}$ cryostat sections. Corneal tissue was processed as free-floating sections.

Ligated sciatic nerve. Male Sprague Dawley rats (300-400 gm) were induced with $2 \%$ isoflurane and maintained on $2 \%$ isoflurane delivered over a fitted nose cone. A $1 \mathrm{~cm}$ incision was made over the left lateral thigh, and the sciatic nerve was exposed by blunt dissection. The nerve was tied tightly with two $0-0$ silk ligatures and transected with a scalpel between the two ligatures, and the overlying muscles and skin were closed in layers. Animals are weighed daily to monitor their level of discomfort after surgery. Animals were killed $3 \mathrm{~d}$ after surgery and perfused as above for fluorescence microscopy.

Immunofluorescence. Primary antisera were as follows: rabbit anti-5$\mathrm{HT}_{1 \mathrm{D}}$ receptor (1:40,000 for slide mounted sections, 1:5000 for whole mounts of dura, and 1:10,000 for free-floating cornea sections), goat anti-peripherin (1:100; Santa Cruz Biotechnology, Santa Cruz, CA), guinea pig anti-substance P (SP) (1:5000; gift from J. Maggio, University of Cincinnati, Cincinnati, OH), and mouse anti-N52 (1:5000; Sigma, St. Louis. MO). Purified mouse monoclonal anti-SSEA3 IgM (1:100) was from the Developmental Studies Hybridoma Bank (University of Iowa, Iowa City, IA). Secondary antisera, all purchased from Jackson ImmunoResearch (West Grove, PA) were Cy2-labeled anti-mouse IgM (1:100), anti-guinea pig $\operatorname{IgG}(1: 100)$, anti-goat $\operatorname{IgG}(1: 60)$, or Cy3-labeled antirabbit $\operatorname{IgG}(1: 600)$.

Slide-mounted sections, free-floating sections, and whole mounts were immunostained in a similar manner. Tissue was incubated for $1 \mathrm{hr}$ in PBS with $0.3 \%$ Triton X-100 (PBST) plus 5\% normal horse serum (NHS). Primary and secondary antisera were diluted in PBST plus $1 \%$ NHS. Tissue was incubated overnight at room temperature in either rabbit anti-5-HT $\mathrm{H}_{1 \mathrm{D}}$ receptor antibody (for single-label studies) or in a mixture of two primary antisera for double-immunofluorescence studies. Between incubations, slides were rinsed in PBS plus 1\% NHS. Tissue was then incubated with either single or mixtures of appropriate secondary antisera, washed in phosphate buffer, and coverslipped using Fluoromont G (Southern Biotechnology Associates, Birmingham, AL). For isolectin B4 (IB4) binding, we added FITC-IB4 (10 $\mu \mathrm{g} / \mathrm{ml}$; Sigma) during the incubation of secondary antibody. A counterstain with $4^{\prime}, 6^{\prime}$ diamidino-2-phenylindole (DAPI) $(1 \mu \mathrm{g} / \mathrm{ml}$; Sigma) was added to the final wash to stain nuclei of slide-mounted sections.

Visualization and quantification. Digitized images were captured with a Nikon Eclipse microscope with an attached Spot CCD camera. Every 10th L5 DRG and every 30th TRG section in a series was stained, imaged, and analyzed in its entirety. Tissues from three rats were used to estimate the percentages of single- and double-labeled neurons. For the nodose ganglion, the pair of ganglia from three rats were mounted en bloc, and every fifth section was examined to count double-labeled neurons in a similar manner. Images were imported into Photoshop (Adobe Systems, San Jose, CA).

The percentage of $5-\mathrm{HT}_{\mathrm{ID}}$-immunoreactive (IR) ganglion cells was estimated by counting the number of $5-\mathrm{HT}_{1 \mathrm{D}}$-IR neurons containing a DAPI counterstained nucleus. The total number of neuronal profiles were determined by counting DAPI-stained nuclei, excluding small profiles corresponding to glia and connective tissue.

The percentage of double-labeled 5- $\mathrm{HT}_{1 \mathrm{D}}$ ganglion cells was determined by counting the total number of neurons with $5-\mathrm{HT}_{1 \mathrm{D}}$ immunoreactivity and identifying how many were labeled with the second neuronal marker. To identify double-labeled ganglion cells, images of the same section of tissue obtained using different filter blocks were overlaid in a single Photoshop file. While viewing an image containing the DAPI signal and Cy3-labeled 5- $\mathrm{HT}_{1 \mathrm{D}}$-IR signal, neurons were identified and marked on an overlaid blank layer. The $\mathrm{Cy} 3$ and DAPI layers were then hidden. The corresponding Cy2-FITC layer was examined for labeled cells. This method of identifying double-labeled neurons was used because $5-\mathrm{HT}_{1 \mathrm{D}}-\mathrm{IR}$ neurons tended to be bright and the Cy3 signal frequently overwhelmed the Cy2-FITC signal. If double-labeled ganglion cells were identified only from superimposed images, many double-labeled neurons would not have been counted. Finally, we determined the percentage of peripherin-immunoreactive, substance P-immunoreative, and IB4binding neurons that colocalized the $5-\mathrm{HT}_{1 \mathrm{D}}$ receptor by dividing the total number of double-labeled neurons by the total number ganglion cells that were immunoreactive for that marker.

Cell diameters were measured using NIH Image. Ganglia sections were imaged in their entirety as a series of digital image files. A random number generator was used to generate lists of files for measurement. Separate lists were created for the DRG and TRG, as well as cell type, such as densely labeled and punctate-labeled $5-\mathrm{HT}_{1 \mathrm{D}}-\mathrm{IR}$ ganglion cells (see Results). The length of the long and short axes of all of the neurons that were present in every selected file was measured. Counts were concluded when 100 or more neurons of interest were measured. The diameter of each cell was calculated as the square root of its length multiplied by its width. This expression of diameter allows the direct calculation of area of the cell profile and corrects for the elliptical shape of many neurons. Results are expressed as mean $\pm \mathrm{SD}$.

Diaminobenzidine immunohistochemistry of spinal cord and trigeminal nucleus. Rats were perfused as for fluorescence studies above. After dissection of the brain and spinal cord, the brainstem and lumbar spinal cord were postfixed and cryoprotected in 30\% sucrose, and transverse frozen sections were cut at $50 \mu \mathrm{m}$. These free-floating sections were 
preincubated in 5\% normal goat serum-PBST for $1 \mathrm{hr}$ and then incubated overnight in $1 \%$ normal goat serum-PBST with a 1:50,000 dilution of 5-HT $\mathrm{H}_{1 \mathrm{D}}$ antibody. After three washes, the sections were incubated in a 1:1000 dilution of biotinylated goat anti-rabbit antibody (Jackson ImmunoResearch). To localize the secondary antibody, we used an avitinbiotin HRP protocol with an ABC kit (Vector Laboratories, Burlingame, $\mathrm{CA}$ ) and diaminobenzidine (DAB) (Sigma) as chromogen.

Control experiments for immunocytochemistry. Controls for specificity included immunostaining tissue as above but omitting the primary antisera or adding the appropriate antigen peptide. A homologous absorption control was performed by incubating $5-\mathrm{HT}_{1 \mathrm{D}}$ primary antisera with antigen peptide ( $1.0 \mathrm{~mm}$ to $1.0 \mathrm{~nm}$ ) for $2 \mathrm{hr}$ at room temperature with gentle shaking and then overnight at $4^{\circ} \mathrm{C}$. Staining was abolished at concentrations through $1.0 \mu \mathrm{M}$. At $100 \mathrm{nM}$, we observed a few immunoreactive profiles. Absorption controls were also performed for SP and peripherin. Antisera with the appropriate peptide $\left(10^{-6} \mathrm{M}\right)$ were incubated with the working dilution of the antiserum and anti-5- $\mathrm{HT}_{1 \mathrm{D}}$ antibody overnight at $4^{\circ} \mathrm{C}$. With these solutions, there was a complete loss of staining for the appropriate antigen, whereas the observed staining of $5-\mathrm{HT}_{1 \mathrm{D}}$ receptors was not changed. No cross-reactivity was seen among the secondary antibodies when primary antibodies were omitted.

Cloning of $5-H T_{1 D}$ receptor $c D N A$. A mouse cDNA library was constructed from dorsal root ganglia isolated from adult male C57BL/6 mice using standard methods. Briefly, fresh DRG tissue was dissected from cervical, thoracic, and lumbar levels, solubilized in TRIZOL, and processed per the recommendations of the manufacturer (Invitrogen, Carlsbad, CA). The RNA was further purified by affinity to oligo-dT cellulose using Micro-FastTrack per the recommendations of the manufacturer (Invitrogen). Reverse transcription was performed with oligo-dTprimed mRNA or primed with the SMART II RT primers for 3' rapid amplification of cDNA ends (RACE)-ready and 5' RACE-ready cDNA synthesis, (Clontech, Palo Alto, CA).

The published open reading frame sequence for mouse $5-\mathrm{HT}_{1 \mathrm{D}}$ in the GenBank database (accession numbers NM_008309 and X94908) could not be used to amplify a PCR product of the entire open reading frame because of silent codon differences that occurred only in the $3^{\prime}$ end of the sequence. Instead, a 5- $\mathrm{HT}_{1 \mathrm{D}}$-specific forward primer (CCC ATC CAT CTT GCT CAT TAT CC; nucleotides 615-637 from mouse) was combined with $3^{\prime}$ RACE-ready template and universal primer mix to clone the complete $3^{\prime}$ end of the mRNA. At an annealing temperature of $58^{\circ} \mathrm{C}$ and elongation time of $90 \mathrm{sec}$, a $\sim 1600 \mathrm{bp}$ fragment was obtained and cloned into the TOPO II TA-cloning vector (Invitrogen), and two independent clones were sequenced by termination with fluorescent dideoxynucleotides and analyzed by electrophoresis (Applied Biosystems, Foster City, CA). The resulting sequence is in agreement with the full-length mouse cDNA sequence published by the RIKEN Consortium, (accession number AK082016).

Expression constructs for antibody controls. On the basis of the revised sequence, we designed a primer pair to amplify the open reading frame. The forward primer ATG TCG CTG CCA AAC CAG TCC and the reverse primer GCA AAC AAG AGT CAC CCC CAA ATC CG were used to amplify single-stranded cDNA template using the same amplification protocol described above. The resulting $1135 \mathrm{bp}$ fragment was cloned into the TOPO II vector and sequenced as above. The EcoRI digested insert from this plasmid was cloned into the EcoRI site of the mammalian expression vector pCDNA3. The resulting expression plasmid pC1D-2 was used in the transfection experiment below. The expression plasmid for the mouse $5-\mathrm{HT}_{1 \mathrm{~B}}$ receptor, $1 \mathrm{~B}-\mathrm{p} 514$, and the expression plasmid for the mouse $5-\mathrm{HT}_{1 \mathrm{~F}}$ receptor, $1 \mathrm{~F}-\mathrm{p} 514$, were generous gifts from $\mathrm{R}$. Hen (Columbia University, New York, NY) (Amlaiky et al., 1992; Maroteaux et al., 1992). The expression construct pCDNA3-cGFP was a kind gift from D. Julius (University of California San Francisco, San Francisco, CA).

Transfection control of human epithelial kidney cells. A single plate of human epithelial kidney (HEK) cells were split into a six-well plate for parallel transfection of green fluorescent protein (GFP), $5-\mathrm{HT}_{1 \mathrm{~B}}$, $5-\mathrm{HT}_{1 \mathrm{D}}$, or $5-\mathrm{HT}_{1 \mathrm{~F}}$ expression constructs described above. Transfections of $500 \mathrm{ng}$ of DNA to a near-confluent layer of HEK cells were performed with $5 \mu$ l of Lipofectamine 2000 (Invitrogen) in Opti-MEM low-serum media (Invitrogen). After overnight transfection, the cells were replated onto four-well chamber slides (Fisher Scientific, Houston, TX) pretreated with Matrigel (BD Biosciences, San Jose, CA). Each slide contained four separate samples of HEK cells transfected with GFP, 5- $\mathrm{HT}_{1 \mathrm{~B}}$, $5-\mathrm{HT}_{1 \mathrm{D}}$, or $5-\mathrm{HT}_{1 \mathrm{~F}}$ expression constructs. After overnight incubation, the cells were rinsed in prewarmed Opti-MEM, fixed with $4 \%$ paraformaldehyde in PBS for $10 \mathrm{~min}$, and then rinsed in phosphate buffer, $\mathrm{pH}$ 7.4. The cells were then blocked in 5\% normal goat serum in PBST for 1 $\mathrm{hr}$ at room temperature, followed by overnight incubation at room temperature in $1 \%$ goat serum-PBST containing a 1:50,000 dilution of rabbit anti-5-HT ${ }_{1 D}$ antisera. After three washes in $1 \%$ goat serum-PBST, the rabbit antibody was detected with Cy3-labeled goat anti-rabbit IgG secondary antibody at 1:1000 dilution in 1\% goat serum-PBST for $1 \mathrm{hr}$ at room temperature. After the chamber wells were removed, three washes in phosphate buffer were followed by coverslipping with Fluoromount G. Digital images were acquired as described above.

\section{Electron microscopy}

Tissue preparation. Three adult Sprague Dawley rats were deeply anesthetized and perfused for electron microscopic immunocytochemistry, first with heparin saline and then with (A) 2\% paraformaldehyde, $0.1 \%$ glutaraldehyde, and $0.2 \%$ picric acid, (B) $4 \%$ paraformaldehyde, $0.5 \%$ glutaraldehyde, $0.2 \%$ picric acid, or (C) $4 \%$ paraformaldehyde and $1 \%$ glutaraldehyde, all in $0.1 \mathrm{~m}$ phosphate buffer, $\mathrm{pH}$ 7.4. Tissues fixed with solutions A or B were processed for preembedding immunocytochemistry with primary antibody at 1:50,000 and using a DAB (A) or a silverintensified $1.0 \mathrm{~nm}$ gold method (B) (IntenSE; Amersham Biosciences, Piscataway, NJ) by standard methods to produce flocculent or particulate reaction products, respectively. These were osmicated, dehydrated, and embedded in Durcupan resin, thin sectioned, and counterstained with uranyl acetate and lead citrate before examination in a Jeol (Peabody, MA) electron microscope.

High-pressure freezing of tissue. After fixation C, and after postfixation for $3 \mathrm{hr}, 200 \mu \mathrm{m}$ transverse sections of lumbar spinal cord were cut on a vibratome. From these sections, disks encompassing the dorsal horn were cut with a biopsy punch and placed into a same-sized copper planchette. These were immediately subjected to high-pressure freezing in a EM PACT apparatus (Leica, Vienna, Austria). Frozen tissues were transferred to an AFS apparatus (Leica) for freeze substitution over $3 \mathrm{~d}$ at $-90^{\circ} \mathrm{C}$ in $0.1 \%$ osmium tetroxide and $0.1 \%$ uranyl acetate in acetone. The solutions were changed to anhydrous acetone, and the temperature was raised slowly to $-40^{\circ} \mathrm{C}$. After brief rinses in absolute ethanol, the tissues were infiltrated in the AFS with Lowicryl Monostep HM20 (Electron Microscopy Sciences, Fort Washington, PA) and polymerized by ultraviolet light at $-40^{\circ} \mathrm{C}(2 \mathrm{~d}), 0^{\circ} \mathrm{C}(2 \mathrm{~d})$, and $25^{\circ} \mathrm{C}(1 \mathrm{~d})$.

Postembedding immunocytochemistry. Thin sections of these Lowicryl blocks were mounted on nickel mesh grids and labeled by a modification of the procedure by van Lookeren Campagne et al. (1991). Sections were etched with sodium ethanolate for $2 \mathrm{sec}$, washed, and dried. They were then treated for $10 \mathrm{~min}$ with $0.1 \%$ sodium borohydride and $50 \mathrm{~mm}$ glycine in $0.05 \mathrm{M}$ Tris-buffered saline containing $0.1 \%$ Triton X-100 (TBST) and then blocked in $2 \%$ human serum albumin in TBST. Grids were exposed to a mixture of primary antibodies (guinea pig anti-SP at 1:1000 and rabbit anti-5- $\mathrm{HT}_{1 \mathrm{D}}$ at 1:25,000) in blocking solution for $3 \mathrm{hr}$ at room temperature. After washing, the sections were blocked again and exposed to secondary antibodies [donkey anti-guinea pig conjugated to $6 \mathrm{~nm}$ gold (Jackson ImmunoResearch) and goat anti-rabbit conjugated to $15 \mathrm{~nm}$ gold (Amersham Biosciences) in blocking solution containing $0.5 \mathrm{mg} / \mathrm{ml}$ polyethylene glycol (molecular weight 15,000-20,000; P-2263; Sigma)]. The sections were rinsed, counterstained, and examined in the electron microscope. We observed a consistent localization pattern in crossover controls in which the larger gold particle was conjugated to the antiguinea pig secondary antibody and the smaller gold particle was conjugated to the anti-rabbit secondary antibody.

Preabsorption controls for electron microscopy. Lowicryl sections were treated with $5-\mathrm{HT}_{1 \mathrm{D}}$ antibody and 1.0 or $100 \mu \mathrm{g} / \mathrm{ml} 5-\mathrm{HT}_{1 \mathrm{D}}$ peptide. The grids and the outline of the tissue were sketched, and the labeled axonal boutons were counted in every grid square supporting the region of superficial dorsal horn. An axonal bouton was considered positively la- 

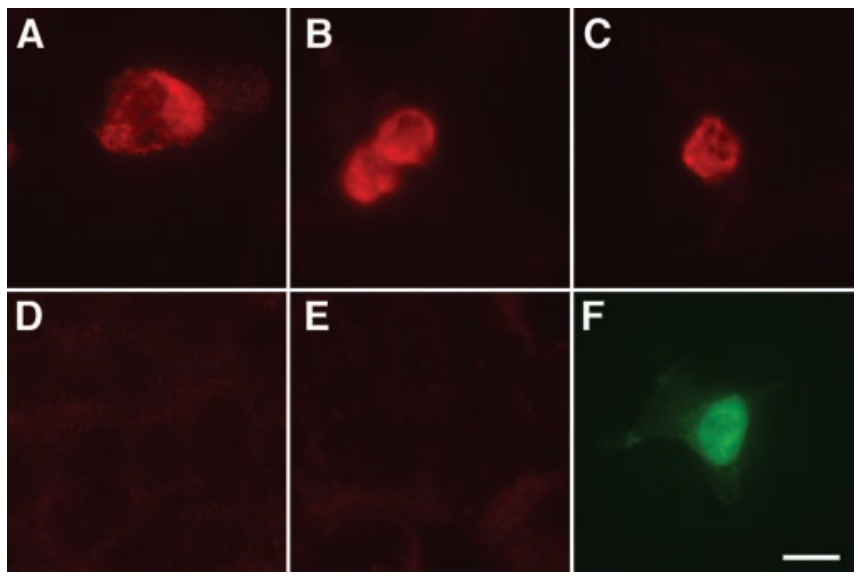

Figure 1. Transfection control of the $5-\mathrm{HT}_{1 \mathrm{D}}$ antibody. HEK were transfected with the mouse CDNA for $5-\mathrm{HT}_{1 \mathrm{D}}(A-C), 5-\mathrm{HT}_{1 \mathrm{~B}}(D)$, or $5-\mathrm{HT}_{1 \mathrm{~F}}(E)$ receptors. $F$, GFP transfection control performed in parallel. There is strong immunoreactivity only when the $5-\mathrm{HT}_{1 \mathrm{D}}$ receptor is expressed. Scale bar, $20 \mu \mathrm{m}$.

beled if it contained two or more gold particles per dense core vesicle (DCV). Sections absorbed with $5-\mathrm{HT}_{1 \mathrm{D}}$ peptide showed rare immunogold label. Incubation of $5-\mathrm{HT}_{1 \mathrm{D}}$ antibody with SP peptide did not reduce $5-\mathrm{HT}_{1 \mathrm{D}}$ label in synaptic terminals.

\section{Results}

\section{Antibody characterization}

After aligning the sequences of the known triptan-responsive receptors in rat, mouse, human, and guinea pig, we identified regions conserved between species but that are unique to the $5-\mathrm{HT}_{1 \mathrm{D}}$ receptor. On the basis of this analysis, we synthesized an oligopeptide that corresponds to a region in the third intracellular loop of the 5-HT 1 receptor and raised antisera in rabbit. The antisera were combined and affinity purified over a columnlinked oligopeptide. This affinity-purified antiserum specifically labels a subpopulation of neurons in anatomical preparations of peripheral ganglia (see below). In our light microscopic preparation, preabsorption of this antibody with $1 \mu \mathrm{M}$ oligopeptide abolished immunostaining. As an additional control, we expressed the cDNA of mouse $5-\mathrm{HT}_{1 \mathrm{~B}}, 5-\mathrm{HT}_{1 \mathrm{D}}$, and $5-\mathrm{HT}_{1 \mathrm{~F}}$ receptors in HEK cells. In conditions that were similar to the immunostaining shown below, we found that HEK cells transfected with 5-HT $\mathrm{HD}_{1 \mathrm{D}}$ cDNA were brightly immunoreactive (Fig. $1 A-C$ ), whereas those transfected with $5-\mathrm{HT}_{1 \mathrm{~B}}$ or $5-\mathrm{HT}_{1 \mathrm{~F}} \mathrm{CDNA}$ showed only background levels of reactivity (Fig. $1 D, E$ ). Finally, we were not able to show antibody specificity by Western blot of tissues or transfected cell lines, presumably because the specificity of the antiserum is lost with heating or denaturation of the tissue.

\section{5- $\mathrm{HT}_{1 \mathrm{D}}$ neurons in peripheral ganglia}

$5-\mathrm{HT}_{1 \mathrm{D}}$ receptors are present in both the lumbar L5 DRG and TRG (Fig. 2), comprising $20 \pm 1$ and $17 \pm 1 \%$, respectively, of the total ganglion cell population. In all $5-\mathrm{HT}_{1 \mathrm{D}}$-IR neurons, we observed a diffuse granular immunocytochemical reaction product in both the cytoplasm and axons, sparing the nucleus. We noted two distinct patterns of immunostaining (Fig. 2C, D). The majority of lumbar $(89 \pm 3 \%)$ and trigeminal $(91 \pm 2 \%) 5-\mathrm{HT}_{1 \mathrm{D}}-\mathrm{IR}$ ganglion cells had a "dense" granular staining pattern, producing a confluent and bright fluorescent signal. In the remaining cells, the reaction product was less dense and had a "punctate" pattern of immunofluorescence.

$5-\mathrm{HT}_{1 \mathrm{D}}$-IR ganglion cells had mean diameters of $25 \pm 5$ and $20 \pm 3 \mu \mathrm{m}$, respectively, in lumbar DRG and TRG. In addition,
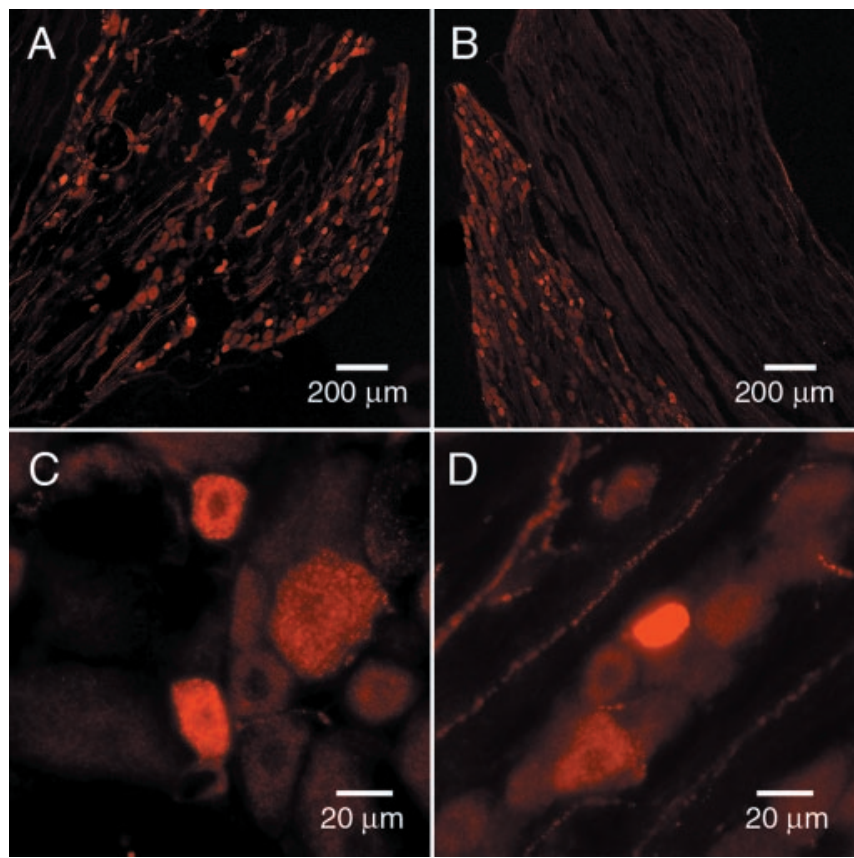

Figure 2. Dense and punctate 5- $\mathrm{HT}_{1 \mathrm{D}}$ immunoreactivity in sensory ganglia. Low-power view shows $5-\mathrm{HT}_{1 \mathrm{D}}-\mathrm{IR}$ neurons in both $\mathrm{L} 5 \mathrm{DRG}(A)$ and TRG $(B)$. Examples of the two patterns of neuronal $5-\mathrm{HT}_{10}$ immunoreactivity, dense and punctate, are seen in DRG $(C$ and TRG $(D)$.

we separately determined the cell diameters of densely labeled neurons from those observed to have a punctate pattern of labeling, as represented in the histogram of cell diameters in Figure 3. Densely immunoreactive cells had mean diameters of $24 \pm 5$ and $19 \pm 3 \mu \mathrm{m}$ in the DRG and TRG, respectively. The much rarer population of punctate $5-\mathrm{HT}_{1 \mathrm{D}}$-IR ganglion cells had larger diameters of $35 \pm 7$ and $27 \pm 4 \mu \mathrm{m}$ for DRG and TRG, respectively.

\section{Neurochemical phenotype of 5- $\mathrm{HT}_{1 \mathrm{D}}$ afferents}

We used a variety of markers to characterize the neurochemistry of ganglion cells that express $5-\mathrm{HT}_{1 \mathrm{D}}$ receptors: peripherin, IB4 binding, and SP for the small-diameter, unmyelinated nociceptors (Goldstein et al., 1991; Lawson et al., 1997; Molliver et al., 1997; Stucky and Lewin, 1999), N52 (NF200), a neurofilament marker of myelinated afferents (Lawson and Waddell, 1991), and SSEA3, which is expressed in a subset of myelinated afferents hypothesized to be low-threshold $\mathrm{A} \beta$ mechanoreceptors (Jessell and Dodd, 1985; Perry and Lawson, 1998).

\section{5- $H T_{1 D}$ and peripherin}

Of those ganglion cells that labeled with $5-\mathrm{HT}_{1 \mathrm{D}}, 84 \pm 1 \%$ of DRG and $83 \pm 1 \% \mathrm{TRG}$ also stained with peripherin (Fig. $4 A$ ). In both ganglia, peripherin was more likely to be colocalized in densely labeled $5-\mathrm{HT}_{1 \mathrm{D}}-\mathrm{IR}$ neurons. Counting only the densely labeled 5- $\mathrm{HT}_{1 \mathrm{D}}$-IR neurons, $91 \pm 2 \%$ DRG and 87\% TRG neurons also stained with peripherin. Among the punctate 5 - $\mathrm{HT}_{1 \mathrm{D}}$-IR neurons, only $44 \pm 4$ and $55 \pm 8 \%$ of the DRG and TRG, respectively, colocalized this marker. Among the peripherin-immunoreactive afferents, $31 \pm 9$ and $31 \pm 11 \%$ were also $5-\mathrm{HT}_{1 \mathrm{D}}-\mathrm{IR}$ in the DRG and TRG, respectively.

\section{5- $H T_{1 D}$ neurons are peptidergic}

The large majority of 5-HT 1 DRG and TRG neurons also colocalized substance $\mathrm{P}(88 \pm 3$ and $88 \pm 1 \%$, respectively) (Fig. $4 C$ ). Among the densely labeled $5-\mathrm{HT}_{1 \mathrm{D}}-\mathrm{IR}$ ganglion cells, the vast majority colocalized substance P: $95 \pm 1$ and $94 \pm 1 \%$ in the DRG 


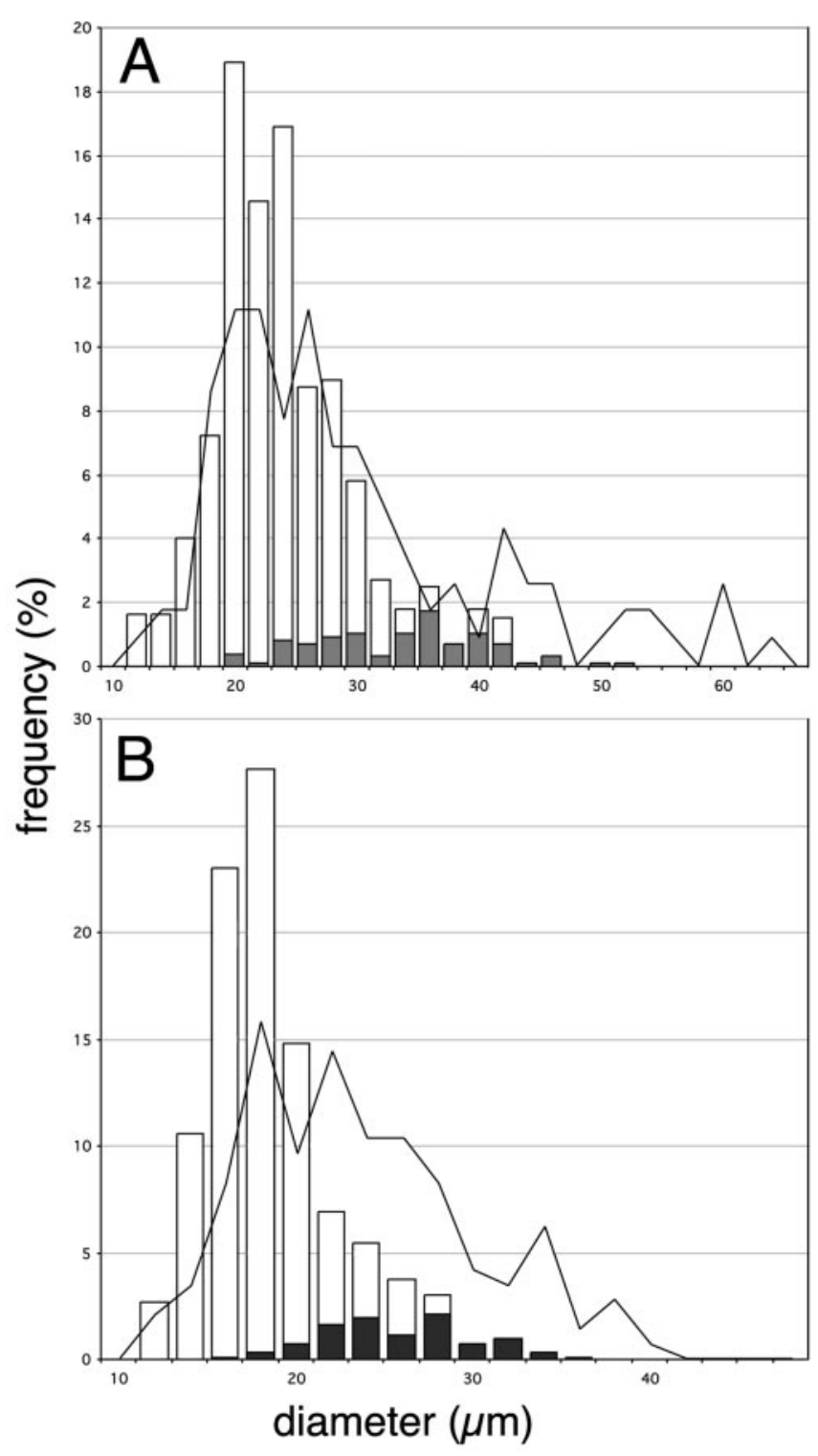

Figure 3. Stacked histogram of the distribution of $5-\mathrm{HT}_{10}-\mathrm{IR}$ neuron diameters in the DRG $(A)$ and TRG $(B)$. The relative contributions of dense (open) and punctate (filled) patterns of immunostaining to the distribution are indicated. The overlaid line graph shows the frequency distribution of cell diameters in the entire DRG or TRG population (both labeled and unlabeled).

and TRG, respectively. Among the much less numerous punctate $5-\mathrm{HT}_{1 \mathrm{D}}$-IR ganglion cells, very few were also immunoreactive for substance P: $9 \pm 8$ and $11 \pm 5 \%$ in DRG and TRG, respectively. However, a large majority, but not all, of the SP-immunoreactive DRG and TRG ganglion cells were also 5-HT $\mathrm{HD}_{1 \mathrm{D}}$ : $69 \pm 3$ and $54 \pm 4 \%$, respectively.

\section{Some 5-HT $T_{1 D}$ neurons bind IB4}

Among 5-HT ${ }_{1 \mathrm{D}}$-IR neurons, $61 \pm 6 \%$ DRG and $60 \pm 3 \%$ TRG neurons also demonstrated IB4 binding (Fig. 4B). As with peripherin, the majority of densely labeled $5-\mathrm{HT}_{1 \mathrm{D}}$ - immunoreactive DRG and TRG neurons bound this marker of nociceptors ( $68 \pm 5$ and $64 \pm 3 \%$, respectively). Only a small minority of punctate $5-\mathrm{HT}_{1 \mathrm{D}}$-IR neurons colocalized IB4 binding: $4 \pm 2 \%$ of DRG and $13 \pm 2 \%$ of TRG neurons. Of the entire population of IB4-positive ganglion cells, we found that $24 \pm 6$ and $23 \pm 2 \%$ are $5-\mathrm{HT}_{1 \mathrm{D}}-\mathrm{IR}$ in the DRG and TRG, respectively.
5-HT ${ }_{1 D}$ and myelinated afferents

We found that a minority of 5- $\mathrm{HT}_{1 \mathrm{D}}$-IR neurons colocalized with N52 (NF200), a marker of cell bodies with myelinated axons: $17 \pm 3 \%$ in the DRG and $15 \pm 4 \%$ in the TRG (Fig. $4 D$ ). Among the densely labeled 5- $\mathrm{HT}_{1 \mathrm{D}}$-IR neurons, only $12 \pm 3$ and $11 \pm 3 \%$ in DRG and TRG, respectively, immunostained for N52. In contrast, N52 immunostaining was more prevalent in punctate 5-HT $\mathrm{HD}_{1 \mathrm{D}}$-IR cells: $62 \pm 10$ and $48 \pm 7 \%$ in DRG and TRG, respectively. Of all of the N52-immunoreactive ganglion cells, $8 \pm 2$ and $7 \pm 5 \%$ contained $5-\mathrm{HT}_{1 \mathrm{D}}$-IR in DRG and TRG, respectively. Finally, in neither ganglion population did we observe 5- $\mathrm{HT}_{1 \mathrm{D}}$ immunoreactivity in neurons that contained SSEA3 immunoreactivity (Fig. 5E).

\section{Central projections of 5-HT $\mathrm{HD}_{1 \mathrm{D}}$ afferents}

Consistent with the presence of 5- $\mathrm{HT}_{1 \mathrm{D}}$ immunoreactivity on predominantly small-diameter, unmyelinated DRG and TRG neurons, we observed dense 5- $\mathrm{HT}_{1 \mathrm{D}}$-IR fiber and terminal labeling in the superficial layers of the trigeminal nucleus caudalis and spinal cord dorsal horn (Fig. 5). The immunoreactivity was concentrated in lamina I and in outer lamina II. There is also a sparse pattern of labeled terminals in deeper laminas of both the trigeminal nucleus caudalis and the spinal dorsal horn. We observed a faint terminal pattern in the nucleus solitarius (NTS), which was most prominent in the midline commissural nucleus (Fig. 5A) but also seen in the ventrolateral subnucleus (data not shown). We did not observe $5-\mathrm{HT}_{1 \mathrm{D}}$-IR cell bodies in the trigeminal nucleus caudalis, dorsal horn, NTS, or cranial nerve nuclei.

\section{$5-\mathrm{HT}_{1 \mathrm{D}}$ in visceral afferents and efferents}

From the very sparse terminal labeling in the NTS, we predicted that very few visceral afferents of the vagus would express $5-\mathrm{HT}_{1 \mathrm{D}}$. In fact, in the nodose ganglion, we observed few but clustered $5-\mathrm{HT}_{1 \mathrm{D}}$-IR neurons (Fig. $6 A-C$ ). Much as for the $5-\mathrm{HT}_{1 \mathrm{D}}$-IR neurons in TRG and DRG, $87.5 \%$ of the $5-\mathrm{HT}_{1 \mathrm{D}}-\mathrm{IR}$ neurons costained for substance $P$.

In the visceral sympathetic efferent neurons of the superior cervical ganglion, we did not detect any $5-\mathrm{HT}_{1 \mathrm{D}}$-IR ganglion cells. However, we did observe occasional $5-\mathrm{HT}_{1 \mathrm{D}}$-IR fibers in the capsular connective tissue around the ganglion (data not shown). These likely correspond to the C-fiber innervation of the sympathetic chain and carotid sheath.

\section{Ultrastructure of 5- $\mathrm{HT}_{1 \mathrm{D}}$ in presynaptic terminals of the spinal cord}

To characterize the subcellular localization of 5- $\mathrm{HT}_{1 \mathrm{D}}$ receptors, we examined the lumbar dorsal horn by electron microscopy. In preliminary analysis using an HRP-DAB immunostaining protocol, it appeared that the flocculent DAB reaction product was predominantly associated with DCVs of synaptic terminals (Fig. $7 A$ ). To more precisely localize the immunoreaction product, we turned to a preembedding approach with a silver-intensified 1 $\mathrm{nm}$ gold technique, which produces a silver-enhanced reaction product that is particulate. Figure $7 B$ illustrates that the immunoreaction product is indeed concentrated around DCVs. Silverenhanced gold particles on other structures, e.g., synaptic membranes, only occurred at background levels.

Because of the extensive overlap of $5-\mathrm{HT}_{1 \mathrm{D}}$ and SP in the sensory ganglion cells and in the superficial dorsal horn, we next examined the ultrastructural relationship of $5-\mathrm{HT}_{1 \mathrm{D}}-\mathrm{IR}$ receptor and SP terminal immunoreactivity in the lumbar spinal cord using a high-pressure freezing and postembedding doublelabeling protocol. The high-pressure freezing protocol better pre- 

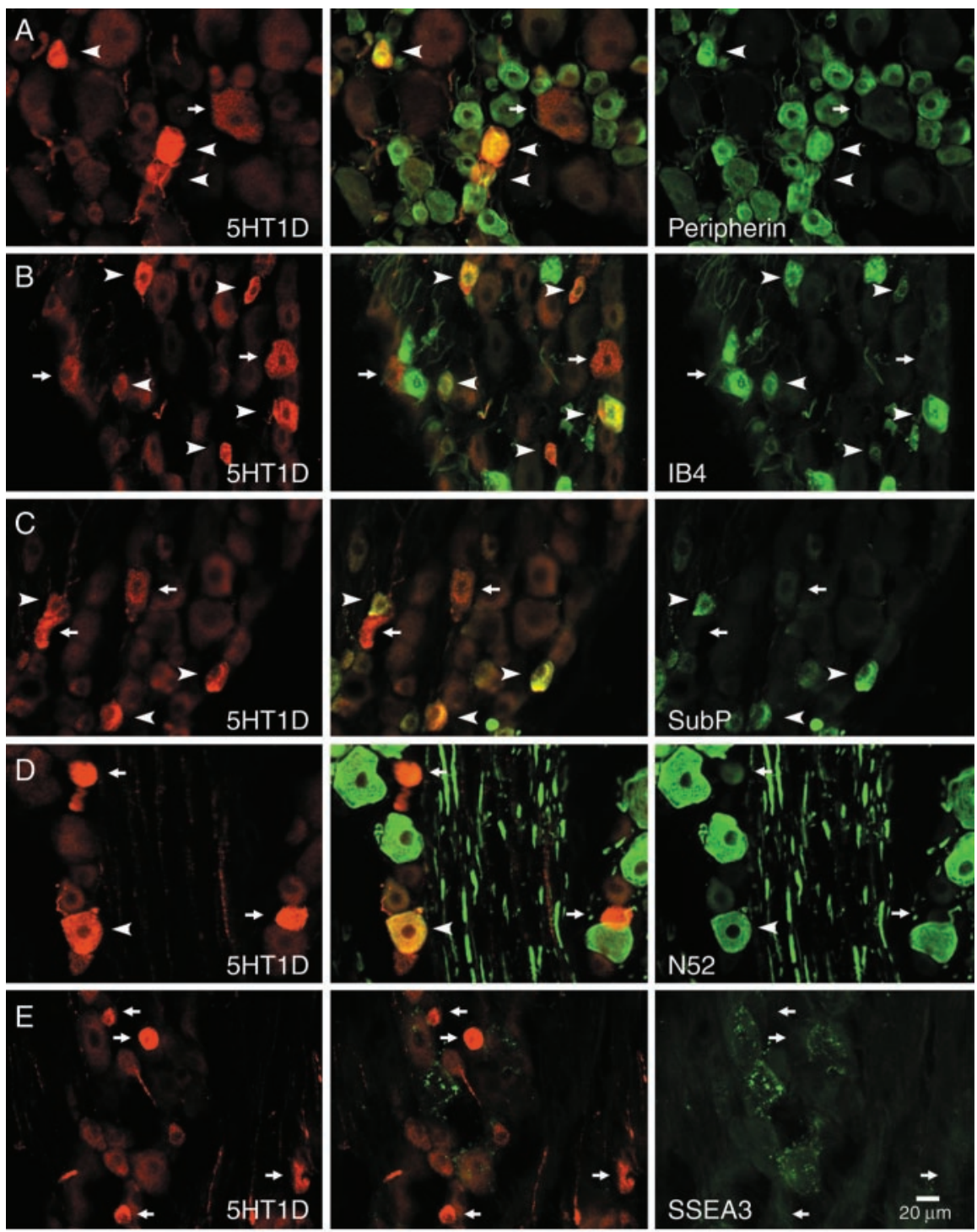

Figure 4. 5- $\mathrm{HT}_{1 \mathrm{D}}$ receptors predominate in nociceptors. Immunofluorescent labeling of ganglion cells in the lumbar $\mathrm{DRG}(A, D$, $E)$ and TRG $(B, C)$. Staining of $5-\mathrm{HT}_{1 \mathrm{D}}$ receptors is shown in the left panels, and colocalization with different markers is shown on the right: peripherin $(A)$, IB4 binding $(B)$, substance $P(C), N 52(D)$, and SSEA3 $(E)$. Middle panels show merged images. Arrowheads, Double-labeled neurons. Arrows, Single-labeled 5- $\mathrm{HT}_{1 \mathrm{D}}$-IR neurons

serves antigen compared with traditional fixation approaches. Different-sized gold particles were used for the two antisera. Figure 7, $C$ and $D$, illustrates the high degree of colocalization of large and small gold particles, indicating that SP and $5-\mathrm{HT}_{1 \mathrm{D}}$ immunoreactivity colocalizes in DCVs.

\section{5- $\mathrm{HT}_{1 \mathrm{D}}$ in peripheral afferent terminals}

To determine the expression of $5-\mathrm{HT}_{1 \mathrm{D}}$ immunoreactivity in cranial tissues that might be relevant in migraine, we immunostained cornea and dura and found $5-\mathrm{HT}_{1 \mathrm{D}}$-IR fibers in both areas (Fig. $8 A, B$ ). Although we have not stained tissues outside of the head, Figure $8 C$ illustrates that there is a buildup of $5-\mathrm{HT}_{1 \mathrm{D}}$ immunoreactivity proximal to the site of sciatic ligation with loss of immunoreactivity distally. This buildup indicates that the receptor is transported peripherally to tissue innervated by the sciatic nerve.

\section{Discussion}

To better understand the mechanisms that underlie the clinical effectiveness of the triptans for migraine therapy, it is important to identify the targets that are influenced by these drugs. To this end, we raised an antiserum that selectively recognizes the $5-\mathrm{HT}_{1 \mathrm{D}}$ receptor. Although our studies do not answer the question as to whether triptans exert their antimigraine actions in the CNS or at peripheral terminals, they do indicate that the primary afferent nociceptor is an important target. We found $5-\mathrm{HT}_{1 \mathrm{D}}$ receptors in both trigeminal and dorsal root ganglia, primarily within small-diameter, unmyelinated, peptidergic nociceptors. Accordingly, there is a dense terminal pattern of 5-HT ${ }_{1 \mathrm{D}}$ immunoreactivity in the superficial laminas of the trigeminal nucleus caudalis and the spinal cord dorsal horn. When these terminals were examined at the electron microscopic level, we found the receptor concentrated in DCVs, which co-contain SP immunoreactivity. This raises the possibility that the release of SP and other cotransmitters can be selectively controlled by the action of $5-\mathrm{HT}_{1 \mathrm{D}}$ receptor. We also found label within visceral afferents of the nodose ganglion and solitary nucleus but did not observe 5- $\mathrm{HT}_{1 \mathrm{D}}$ immunoreactivity within the sympathetic efferents of the superior cervical ganglion.

\section{Do triptans work selectively on trigeminal afferents?}

We found that primary afferent neurons with $5-\mathrm{HT}_{1 \mathrm{D}}$ receptor in the TRG were similar to those in DRG in all characteristics studied: size distribution (Fig. 3), proportional representation, and neurochemical phenotype (Fig. 4). The 5- $\mathrm{HT}_{1 \mathrm{D}}$ afferents project centrally, to laminas I and outer II of trigeminal nucleus caudalis and dorsal horn of the spinal cord (Fig. 5), a distribution that is also consistent with their expression on peptidergic, unmyelinated (i.e., peripherin-positive) nociceptors. Although previously thought to have a specific role in the modulation of neurogenic inflammation in the trigeminal vascular system, 5- $\mathrm{HT}_{1 \mathrm{D}}$ receptors are clearly positioned to regulate neurogenic inflammation and nociceptive processing in diverse regions of the body.

\section{$5-\mathrm{HT}_{1 \mathrm{D}}$ in sensory neurons}

\section{5-HT ${ }_{1 D}$ and unmyelinated afferents}

The neurons that contain $5-\mathrm{HT}_{1 \mathrm{D}}$-IR account for $\sim 20 \%$ of the total ganglion cell population. This is less than previous estimates for the TRG and may reflect a higher selectivity for $5-\mathrm{HT}_{1 \mathrm{D}}$ immunoreactivity by the antibody used in the present study compared with previous studies. The distribution of cell diameters of densely labeled $5-\mathrm{HT}_{1 \mathrm{D}}$-IR cells (Fig. 3) is consistent with their presence on small unmyelinated neurons. The great majority of the $5-\mathrm{HT}_{1 \mathrm{D}}$-IR sensory ganglion cells colocalize with both peripherin and SP (Fig. $4 A, C$ ), suggesting that the receptor is pri- 

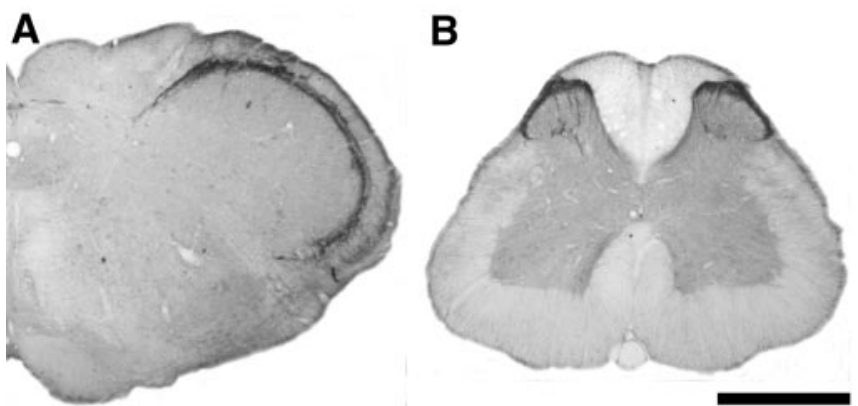

Figure 5. $5-\mathrm{HT}_{10}$ expression in the trigeminal nucleus caudalis and lumbar spinal cord of the rat. These $50 \mu \mathrm{m}$ sections of the caudal medulla and lumbar spinal cord were stained with $5-\mathrm{HT}_{10}$ antibody and HRP detected by reaction with DAB. $A$, There is dense terminal immunoreactivity in the trigeminal nucleus and much lighter terminal labeling in the solitary nucleus. $B$, There is also dense terminal staining in the superficial laminas of the dorsal horn. Scale bar, $1 \mathrm{~mm}$.

marily associated with primary afferent, unmyelinated nociceptors (Goldstein et al., 1991; Lawson et al., 1997).

\section{IB4}

Although IB4-positive cells have traditionally been considered "peptide-poor" nociceptors (Snider and McMahon, 1998), nearly one-fourth of IB4-binding neurons also express 5- $\mathrm{HT}_{1 \mathrm{D}}$, implying a significant overlap in IB4 binding and SP in $5-\mathrm{HT}_{1 \mathrm{D}}$-IR afferents. Our findings corroborate a recent report that nearly $30 \%$ of IB4-binding TRG and DRG neurons colocalize SP (Price et al., 2002). Together with the localization of the $\mathrm{P} 2 \mathrm{X}_{3}$ receptor and members of the Mrg receptor superfamily to subpopulations of the IB4-positive neurons (Guo et al., 1999; Dong et al., 2001; Han et al., 2002), these data underscore the functional diversity of IB4-positive nociceptors.

\section{Substance $P$}

Our estimate that $88 \%$ of $5-\mathrm{HT}_{1 \mathrm{D}}$-IR TRG neurons colocalize with SP underscores the association of this receptor with nociceptors (Lawson et al., 1997). Our findings are similar to the $95 \%$ concordance with SP in 5- $\mathrm{HT}_{1 \mathrm{D}}$-IR neurons found in human TRG (Hou et al., 2001; Smith et al., 2002) but is much higher than the estimate of $7 \%$ in guinea pig (Bonaventure et al., 1998). In another study of rat TRG, the finding that $75 \%$ of $5-\mathrm{HT}_{1 \mathrm{D}}-\mathrm{IR}$ neurons also localize with calcitonin gene-related peptide is consistent with its association with peptidergic neurons (Ma et al., 2001). On the other hand, our finding that no more than threefourths of all SP-immunoreactive neurons are also $5-\mathrm{HT}_{1 \mathrm{D}}-\mathrm{IR}$ should caution against simply equating triptan action with modulation of SP.

Subset of 5-HT $T_{1 D}-I R$ neurons are myelinated

We observed two different staining patterns among the 5- $\mathrm{HT}_{1 \mathrm{D}}$ neurons, dense and punctate. Interestingly, although much less
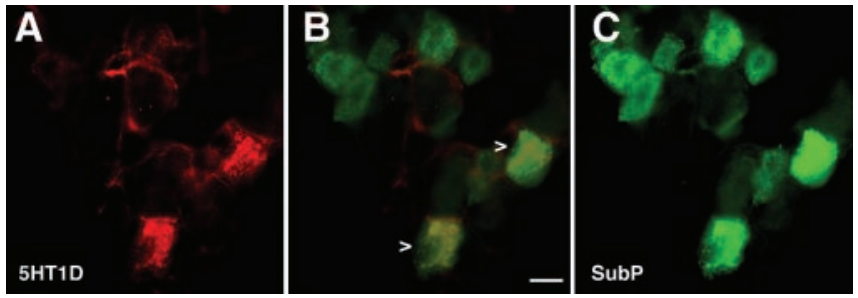

Figure 6. $5-\mathrm{HT}_{1 \mathrm{D}}$ colocalizes with a subpopulation of peptidergic visceral afferents in the nodose ganglia. $A, 5-\mathrm{HT}_{10}$. C, SP. B, Merged image shows that a subset of SP visceral afferents are double labeled with $5-\mathrm{HT}_{10}$ receptor (arrowheads). Scale bar, $20 \mu \mathrm{m}$.
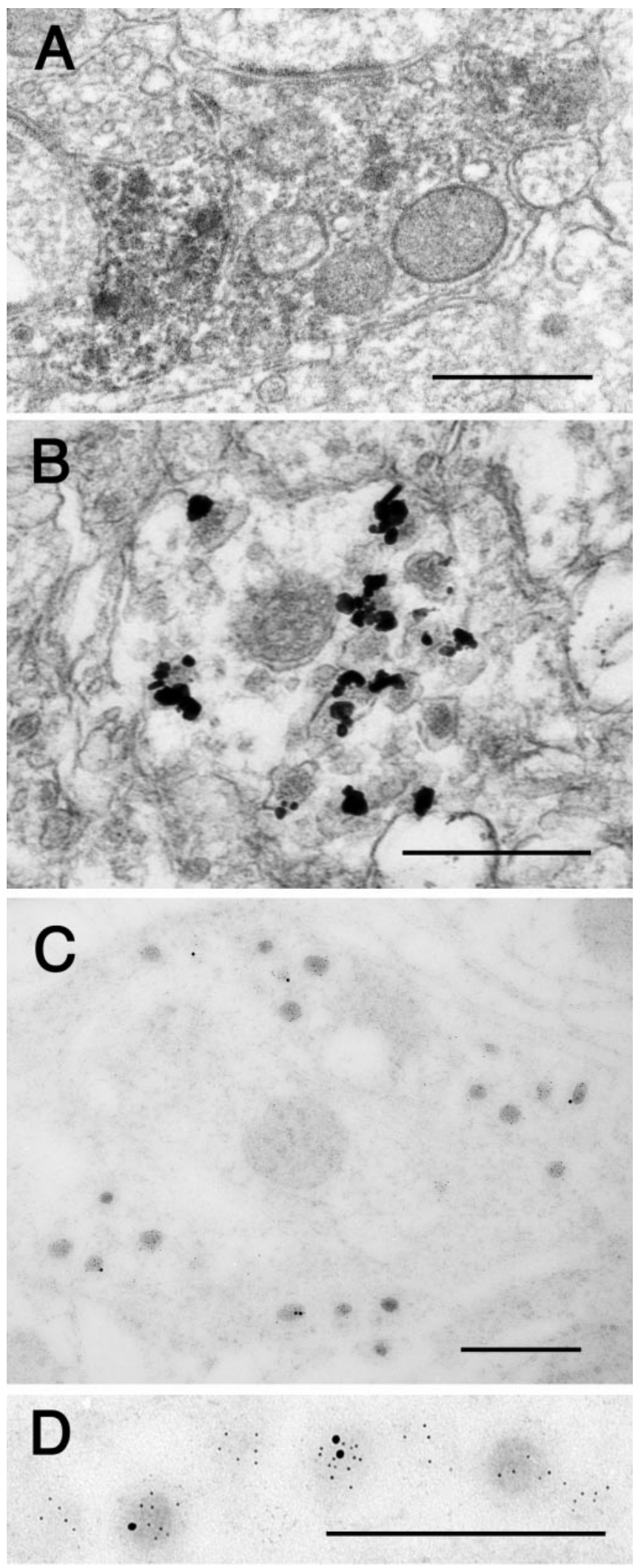

Figure 7. Electron microscopic immunolocalization of $5-\mathrm{HT}_{10}$ in DCVs of terminals in lamina I. $A$, These terminals, immunolabeled with $\mathrm{HRP}$ and $\mathrm{DAB}$, show a flocculent $5-\mathrm{HT}_{10}$ immunoreaction product that is most strongly concentrated over DCVs. B, Immunolabeling with a silver intensified preembedding method also shows label only overthe DCVs. C, D, Double-label postembedding immunogold reveals colocalization of $5-\mathrm{HT}_{1 \mathrm{D}}(15 \mathrm{~nm}$ gold particles) and SP ( $6 \mathrm{~nm}$ gold particles) in the same $\mathrm{DCV}$ s. This single large axon terminal hasfour peripheral groups ofDCVs in theplane of section, each of which is immunoreactive for both antigens. D shows the immunolabeling from a different terminal athigher magnification. Scale bars, $0.5 \mu \mathrm{m}$. 

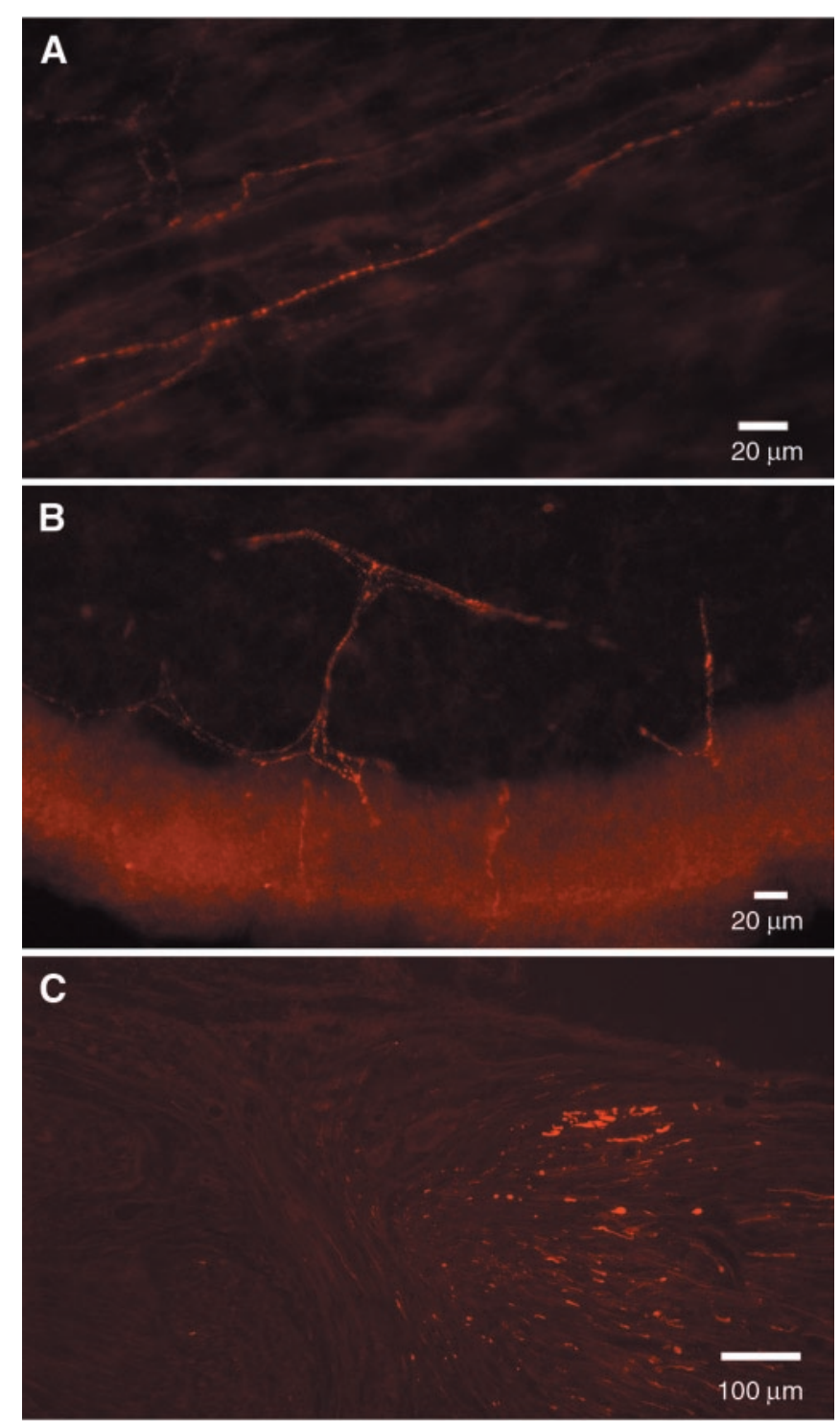

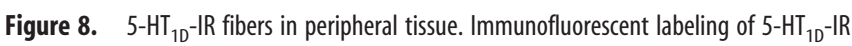
fibers in dura $(A)$, cornea $(B)$, and ligated sciatic nerve ( $C$. In $C$, there is buildup of label proximal to the ligature (right) with much reduced label distally.

abundant, punctate $5-\mathrm{HT}_{1 \mathrm{D}}$-IR neurons are larger, very rarely label with SP, and are more likely to contain neurofilament markers of myelinated neurons. They clearly appear to identify a separate population of $5-\mathrm{HT}_{1 \mathrm{D}}$ receptor-expressing primary afferent. Whether they correspond to lightly myelinated Ad fiber nociceptors remains to be determined, but the fact that we did not find 5- $\mathrm{HT}_{1 \mathrm{D}}$ immunoreactivity in SSEA-3-positive neurons is consistent with this hypothesis (Fig. $4 E$ ).

\section{5-HT ${ }_{1 D}$ in visceral afferents and efferents}

In the nodose ganglion (Fig. 6), nearly all of those afferents with $5-\mathrm{HT}_{1 \mathrm{D}}$ immunoreactivity also costained for SP. Consistent with the paucity of $5-\mathrm{HT}_{1 \mathrm{D}}$-IR afferents in the nodose ganglion, we found few fibers in the solitary nucleus of the brainstem (Fig. $5 \mathrm{~A}$ ). The fact that the immunoreactivity was concentrated in the ventrolateral and commissural subnuclei of the solitary nucleus suggests that activity at these receptors could influence visceral afferent input from heart, lungs, and gastrointestinal tract (Wallach and Loewy, 1980; Davies and Kalia, 1981; Kalia and Sullivan,
1982; Erickson and Millhorn, 1991). It has been proposed that $5-\mathrm{HT}_{1 \mathrm{D}}$ receptor activation of afferents to the solitary nucleus contributes to the relief from nausea that accompanies treatment of migraine (Longmore et al., 1997), although we are not aware of triptans having anti-emetic properties outside the setting of migraine. The $5-\mathrm{HT}_{1 \mathrm{D}}$ receptor appears to be confined to primary afferents, because we did not detect $5-\mathrm{HT}_{1 \mathrm{D}}$ immunoreactivity in the visceral efferents of the superior cervical ganglia. Thus, the relief of gastrointestinal symptoms and gastric immobility by triptans are probably not attributable to their direct action on sympathetic efferents. Although triptans can be used to relieve cluster headache, a disorder with prominent autonomic symptoms (Ekbom et al., 1995), the basis of these effects are probably not attributable to the action of $5-\mathrm{HT}_{1 \mathrm{D}}$ receptor on parasympathetic preganglionic neurons.

\section{$5-\mathrm{HT}_{1 \mathrm{D}}$ in dense core vesicles}

Given that a functional presynaptic receptor would be found on the plasma membrane, the restricted localization of $5-\mathrm{HT}_{1 \mathrm{D}}$ receptors to DCVs (Fig. 7) was unexpected. If the receptor is concentrated in DCVs, but less abundant along the plasma membrane, it may only be detectable in the vesicles. It is also possible that the antigen exists in a different conformational state in the plasma membrane, one that masks the epitope that is recognized by the antibody. Indeed, immunologically discrete forms of a receptor may be directed to different subcellular compartments (Cahill et al., 2001). Alternately, receptors at the plasma membrane may be quickly recycled and degraded soon after vesicular delivery to the membrane, thus maintaining a low steady state in the plasma membrane compared with DCVs.

\section{$5-\mathrm{HT}_{1 \mathrm{D}}$ receptors and the regulation of nociceptive transmission}

Other presynaptic receptors have been localized to DCVs, including the $\delta$-opioid receptor (Cheng et al., 1995), which also may serve to regulate the release of neurotransmitters from primary afferent nociceptors. The localization of $5-\mathrm{HT}_{1 \mathrm{D}}$ receptors within the DCVs of peptidergic nociceptors suggests that this receptor is most relevant under conditions of relatively intense or highfrequency stimulation, which is required for release of DCV contents (Marvizon et al., 1997). In behavioral studies, SP comes into play under conditions of intense stimulation, but SP does not contribute to baseline nociceptive responses (Cao et al., 1998). According to this mechanism, only nociceptive stimulation of sufficient intensity to trigger delivery of DCV s and 5- $\mathrm{HT}_{1 \mathrm{D}}$ receptor to the plasma membrane would make $5-\mathrm{HT}_{1 \mathrm{D}}$ receptors available for interaction with endogenous serotonin or exogenous triptan, at either the central or peripheral terminal. If the functional impact of the receptor depends on the previous activation of the primary afferent that sequesters this receptor, then the $5-\mathrm{HT}_{1 \mathrm{D}}$ receptor would only participate in a subset of nociceptive processes and would thus have a limited analgesic spectrum.

\section{How are triptans "migraine-specific?"}

Our localization of 5-HT $\mathrm{HD}_{1 \mathrm{D}}$ IR nerve fibers within the dura (Fig. $8 A$ ) agrees with a previous study (Longmore et al., 1997). The demonstration that $5-\mathrm{HT}_{1 \mathrm{D}}$-IR fibers are found in the cornea (Fig. $8 \mathrm{~B}$ ) may underlie the analgesic effect of triptans after corneal surgery in a small case series (May et al., 2002). On the other hand, the presence of $5-\mathrm{HT}_{1 \mathrm{D}}$ receptors in lumbar DRG and in the sciatic nerve suggests that the receptor is targeted to sites 
outside of the head. On the basis of this widespread distribution, we cannot conclude that there is a simple anatomical basis for the preferential action of triptans on $5-\mathrm{HT}_{1 \mathrm{D}}$ receptors for the pain of migraine. The same is true for possible triptan actions via the $5-\mathrm{HT}_{1 \mathrm{~B}}$ receptor, which is not restricted to cranial targets on arterial blood vessels and primary afferents (Longmore et al., 1997; Wotherspoon and Priestley, 2000).

Conceivably, some other unique feature of triptan-responsive TRG afferents may confer triptan selectivity to migraine. For example, a difference in the complement of second messengers that lie downstream to this G-protein-coupled receptor may underlie this differential response. The hypothetical distinction between TG and DRG afferents has yet to be rigorously tested but is a fundamental question of great interest.

\section{References}

al Balawi S, Tariq M, Feinmann C (1996) A double-blind, placebocontrolled, crossover, study to evaluate the efficacy of subcutaneous sumatriptan in the treatment of atypical facial pain. Int J Neurosci 86:301-309.

Amlaiky N, Ramboz S, Boschert U, Plassat JL, Hen R (1992) Isolation of a mouse "5HT1E-like" serotonin receptor expressed predominantly in hippocampus. J Biol Chem 267:19761-19764.

Antonaci F, Pareja JA, Caminero AB, Sjaastad O (1998) Chronic paroxysmal hemicrania and hemicrania continua: lack of efficacy of sumatriptan. Headache 38:197-200.

Bonaventure P, Voorn P, Luyten WH, Leysen JE (1998) 5HT1B and 5HT1D receptor mRNA differential co-localization with peptide mRNA in the guinea pig trigeminal ganglion. NeuroReport 9:641-645.

Bouchelet I, Case B, Olivier A, Hamel E (2000) No contractile effect for 5-HT1D and 5-HT1F receptor agonists in human and bovine cerebral arteries: similarity with human coronary artery. $\mathrm{Br} \mathrm{J}$ Pharmacol 129:501-508.

Bruinvels AT, Landwehrmeyer B, Gustafson EL, Durkin MM, Mengod G, Branchek TA, Hoyer D, Palacios JM (1994) Localization of 5-HT1B, 5-HT1D alpha, 5-HT1E and 5-HT1F receptor messenger RNA in rodent and primate brain. Neuropharmacology 33:367-386.

Cahill CM, Morinville A, Lee MC, Vincent JP, Collier B, Beaudet A (2001) Prolonged morphine treatment targets $\delta$-opioid receptors to neuronal plasma membranes and enhances delta-mediated antinociception. J Neurosci 21:7598-7607.

Cao YQ, Mantyh PW, Carlson EJ, Gillespie AM, Epstein CJ, Basbaum AI (1998) Primary afferent tachykinins are required to experience moderate to intense pain. Nature 392:390-394.

Cheng PY, Svingos AL, Wang H, Clarke CL, Jenab S, Beczkowska IW, Inturrisi CE, Pickel VM (1995) Ultrastructural immunolabeling shows prominent presynaptic vesicular localization of $\delta$-opioid receptor within both enkephalin- and nonenkephalin-containing axon terminals in the superficial layers of the rat cervical spinal cord. J Neurosci 15:5976-5988.

Cumberbatch MJ, Hill RG, Hargreaves RJ (1997) Rizatriptan has central antinociceptive effects against durally evoked responses. Eur J Pharmacol 328:37-40

Cumberbatch MJ, Hill RG, Hargreaves RJ (1998) Differential effects of the $5 \mathrm{HT} 1 \mathrm{~B} / 1 \mathrm{D}$ receptor agonist naratriptan on trigeminal versus spinal nociceptive responses. Cephalalgia 18:659-663.

Cumberbatch MJ, Williamson DJ, Mason GS, Hill RG, Hargreaves RJ (1999) Dural vasodilation causes a sensitization of rat caudal trigeminal neurones in vivo that is blocked by a $5-\mathrm{HT} 1 \mathrm{~B} / 1 \mathrm{D}$ agonist. $\mathrm{Br} \mathrm{J}$ Pharmacol 126:1478-1486.

Dao TT, Lund JP, Remillard G, Lavigne GJ (1995) Is myofascial pain of the temporal muscles relieved by oral sumatriptan? A cross-over pilot study. Pain 62:241-244.

Davies RO, Kalia M (1981) Carotid sinus nerve projections to the brain stem in the cat. Brain Res Bull 6:531-541.

Dong X, Han S, Zylka MJ, Simon MI, Anderson DJ (2001) A diverse family of GPCRs expressed in specific subsets of nociceptive sensory neurons. Cell 106:619-632.

Ekbom K, Krabbe A, Micieli G, Prusinski A, Cole JA, Pilgrim AJ, Noronha D,
Micelli G (1995) Cluster headache attacks treated for up to three months with subcutaneous sumatriptan $(6 \mathrm{mg})$. Sumatriptan Cluster Headache Long-term Study Group. Cephalalgia 15:230-236.

Erickson JT, Millhorn DE (1991) Fos-like protein is induced in neurons of the medulla oblongata after stimulation of the carotid sinus nerve in awake and anesthetized rats. Brain Res 567:11-24.

Goadsby PJ, Lipton RB, Ferrari MD (2002) Migraine-current understanding and treatment. N Engl J Med 346:257-270.

Goldstein ME, House SB, Gainer H (1991) NF-L and peripherin immunoreactivities define distinct classes of rat sensory ganglion cells. J Neurosci Res 30:92-104.

Guo A, Vulchanova L, Wang J, Li X, Elde R (1999) Immunocytochemical localization of the vanilloid receptor 1 (VR1): relationship to neuropeptides, the P2X3 purinoceptor and IB4 binding sites. Eur J Neurosci 11:946-958.

Han SK, Dong X, Hwang JI, Zylka MJ, Anderson DJ, Simon MI (2002) Orphan $\mathrm{G}$ protein-coupled receptors MrgA1 and $\mathrm{MrgC} 11$ are distinctively activated by RF-amide-related peptides through the $\mathrm{G} \alpha \mathrm{q} / 11$ pathway. Proc Natl Acad Sci USA 99:14740-14745.

Hoskin KL, Goadsby PJ (1998) Comparison of more and less lipophilic serotonin $(5 \mathrm{HT} 1 \mathrm{~B} / 1 \mathrm{D})$ agonists in a model of trigeminovascular nociception in cat. Exp Neurol 150:45-51.

Hou M, Kanje M, Longmore J, Tajti J, Uddman R, Edvinsson L (2001) 5-HT(1B) and 5-HT(1D) receptors in the human trigeminal ganglion: co-localization with calcitonin gene-related peptide, substance $\mathrm{P}$ and nitric oxide synthase. Brain Res 909:112-120.

Jessell TM, Dodd J (1985) Structure and expression of differentiation antigens on functional subclasses of primary sensory neurons. Philos Trans R Soc Lond B Biol Sci 308:271-281.

Kalia M, Sullivan JM (1982) Brainstem projections of sensory and motor components of the vagus nerve in the rat. J Comp Neurol 211:248-265.

Kayser V, Aubel B, Hamon M, Bourgoin S (2002) The antimigraine 5-HT(1B/1D) receptor agonists, sumatriptan, zolmitriptan and dihydroergotamine, attenuate pain-related behaviour in a rat model of trigeminal neuropathic pain. Br J Pharmacol 137:1287-1297.

Launer LJ, Terwindt GM, Ferrari MD (1999) The prevalence and characteristics of migraine in a population-based cohort: the GEM study. Neurology 53:537-542.

Lawson SN, Waddell PJ (1991) Soma neurofilament immunoreactivity is related to cell size and fibre conduction velocity in rat primary sensory neurons. J Physiol (Lond) 435:41-63.

Lawson SN, Crepps BA, Perl ER (1997) Relationship of substance P to afferent characteristics of dorsal root ganglion neurones in guinea-pig. J Physiol (Lond) 505:177-191.

Longmore J, Shaw D, Smith D, Hopkins R, McAllister G, Pickard JD, Sirinathsinghji DJ, Butler AJ, Hill RG (1997) Differential distribution of 5-HT1D- and 5-HT1B-immunoreactivity within the human trigeminocerebrovascular system: implications for the discovery of new antimigraine drugs. Cephalalgia 17:833-842.

Ma QP, Hill R, Sirinathsinghji D (2001) Colocalization of CGRP with $5-\mathrm{HT} 1 \mathrm{~B} / 1 \mathrm{D}$ receptors and substance $\mathrm{P}$ in trigeminal ganglion neurons in rats. Eur J Neurosci 13:2099-2104.

Maroteaux L, Saudou F, Amlaiky N, Boschert U, Plassat JL, Hen R (1992) Mouse 5HT1B serotonin receptor: cloning, functional expression, and localization in motor control centers. Proc Natl Acad Sci USA 89:3020-3024.

Marvizon JC, Martinez V, Grady EF, Bunnett NW, Mayer EA (1997) Neurokinin 1 receptor internalization in spinal cord slices induced by dorsal root stimulation is mediated by NMDA receptors. J Neurosci 17:8129-8136.

May A, Gamulescu MA, Bogdahn U, Lohmann CP (2002) Intractable eye pain: indication for triptans. Cephalalgia 22:195-196.

Molliver DC, Wright DE, Leitner ML, Parsadanian AS, Doster K, Wen D, Yan Q, Snider WD (1997) IB4-binding DRG neurons switch from NGF to GDNF dependence in early postnatal life. Neuron 19:849-861.

Perry MJ, Lawson SN (1998) Differences in expression of oligosaccharides, neuropeptides, carbonic anhydrase and neurofilament in rat primary afferent neurons retrogradely labelled via skin, muscle or visceral nerves. Neuroscience 85:293-310.

Pierce PA, Xie GX, Meuser T, Peroutka SJ (1997) 5-Hydroxytryptamine receptor subtype messenger RNAs in human dorsal root ganglia: a polymerase chain reaction study. Neuroscience 81:813-819.

Price TJ, Helesic G, Hargreaves KM, Flores CM (2002) Quantitative evalu- 
ation of sensory neuronal sub-population markers in the rat: comparisons between dorsal root and trigeminal ganglia. In: 10th World Congress on Pain, p 367. San Diego: International Association for the Study of Pain.

Skingle M, Birch PJ, Leighton GE, Humphrey PP (1990) Lack of antinociceptive activity of sumatriptan in rodents. Cephalalgia 10:207-212.

Smith D, Hill RG, Edvinsson L, Longmore J (2002) An immunocytochemical investigation of human trigeminal nucleus caudalis: CGRP, substance $\mathrm{P}$ and 5-HT1D-receptor immunoreactivities are expressed by trigeminal sensory fibres. Cephalalgia 22:424-431.

Snider WD, McMahon SB (1998) Tackling pain at the source: new ideas about nociceptors. Neuron 20:629-632.

Storer RJ, Goadsby PJ (1997) Microiontophoretic application of serotonin
(5HT)1B/1D agonists inhibits trigeminal cell firing in the cat. Brain 120:2171-2177.

Stucky CL, Lewin GR (1999) Isolectin B(4)-positive and -negative nociceptors are functionally distinct. J Neurosci 19:6497-6505.

van Lookeren Campagne M, Oestreicher AB, van der Krift TP, Gispen WH, Verkleij AJ (1991) Freeze-substitution and Lowicryl HM20 embedding of fixed rat brain: suitability for immunogold ultrastructural localization of neural antigens. J Histochem Cytochem 39:1267-1279.

Wallach JH, Loewy AD (1980) Projections of the aortic nerve to the nucleus tractus solitarius in the rabbit. Brain Res 188:247-251.

Wotherspoon G, Priestley JV (2000) Expression of the 5-HT1B receptor by subtypes of rat trigeminal ganglion cells. Neuroscience 95:465-471. 